\title{
ANALISIS KINERJA KEUANGAN KOPERASI UNIT DESA DI KECAMATAN TEBING TINGGI KABUPATEN TANJUNG JABUNG BARAT
}

\author{
Ayu Primadiptha Gevinanda ${ }^{1}$, Zulkifli Alamsyah ${ }^{2}$ dan Saidin Nainggolon ${ }^{2}$ \\ 1) Alumni Jurusan Agribisnis Fakultas Pertanian Universitas Jambi, \\ 2) Staf Pengajar Jurusan Agribisnis Fakultas Pertanian Universitas Jambi \\ Email: Ayu_Primadiptha@yahoo.com
}

\begin{abstract}
ABSTRAK
Penelitian ini bertujuan untuk mengetahui keadaan keuangan, kinerja keuangan dan manfaat yang dirasakan anggota Koperasi Unit Desa di Kecamatan Tebing Tinggi. Penelitian ini dilakukan pada KUD Suka Makmur, KUD Sawit Mandiri, KUD Karya Mandiri, KUD Karya Tani dan KUD Harapan Makmur dengan pendekatan rasio keuangan dan mendeskriptifkan manfaat yang dirasakan anggota. Kondisi keuangan menunjukkan bahwa KUD Suka Makmur, KUD Sawit Mandiri, KUD Karya Mandiri, dan KUD Harapan Makmur memiliki modal lebih besar dibandingkan dengan hutang yang ditanggung. Sedangkan KUD Karya Tani memiliki hutang yang lebih besar dibandingkan dengan modal yang dimiliki. Dari hasil perhitungan likuditas KUD di Kecamatan Tebing Tinggi mampu menjamin hutang yang dimiliki dengan aktiva lancar dan persediaan, namun KUD tidak mampu menjamin hutang dengan kas dan bank, karena KUD memiliki saldo kas yang kecil. Dari hasil perhitungan rasio solvabilitas menyatakan KUD mampu memenuhi kewajiban jangka panjangnya.Dari hasil perhitungan profitabilitas KUD mampu menghasilkan laba dari usaha yang dijalankan. Dari perhitungan rasio aktivitas KUD memiliki nilai perputaran dana pada persediaan, aktiva tetap dan dana pada piutang yang baik. Peran koperasi bertujuan untuk mensejahterakan anggota dengan memberikan manfaat sosial dan ekonomi. Berdasakan hasil penelitian KUD telah memberikan manfaat yang dapat dirasakan oleh anggota dengan baik, namun manfaat yang diberikan KUD Harapan Makmur masih kurang dirasakan oleh anggota, karena kurangnya terjalinnya komunikasi dengan anggota, kurangnya pelayanan, barang-barang yang dijual masih terbatas dan pembagian SHU yang dibagikan belum meringankan beban kebutuhan anggota.
\end{abstract}

Kata Kunci : Koperasi Unit Desa, Kinerja Keuangan, Manfaat Sosial dan Ekonomi.

\section{ABSTRACT}

This research aims to determine the financial condition, financial performance and the perceived benefits by the members of the Village Unit Cooperative residing in Tebing Tinggi District. This research was conducted in KUD Suka Makmur, KUD Sawit Mandiri, KUD Karya Mandiri, KUDKarya Taniand KUD Harapan Makmur with financial ratios approach and describe the perceived benefits of the membership. Financial condition indicates that the KUD Suka Makmur, KUD Sawit Mandiri, KUD Karya Mandiri, and KUD Harapan Makmur have the greater financial capital than the debt incurred, while the Karya Tani KUD has a debt that is greater than the owned capital. From the liquidity calculation, KUDs in Tebing Tinggi District are able to guarantee the debt held with current assets and inventory, but KUDs are not able to guarantee the debt with cash and bank because KUDs have small cash balances. From the calculation of the solvency ratio expressed that KUDs are able to meet its long-term obligations. From the calculation of the profitability, KUDs in the are able to generate profits from the business carried on. From the calculation of the ratio of activity, KUDs in have a cycle value of funds in inventory, fixed assets and funds in good receivable. The role of cooperatives aimed at the welfare of members by providing social and economic benefits. Based on the research results, KUDs have given the benefit that can be perceived by the members well, but the benefits provided by KUD Harapan Makmur is still less felt by members because of the lack of establishment of communication with members, lack of services, goods sold are still limited and the division of SHU shared does not ease the burden on members' needs.

Keywords: Village Unit Cooperative, Financial Performance, Social and Economic benefits. 


\section{PENDAHULUAN}

Koperasi Unit Desa menjadi tumpuan harapan petani serta merupakan lembaga yang mendukung perkembangan agribisnis diperdesaan. Sebagai badan usaha, koperasi harus mampu meningkatkan efisiensi kerja sesuai dengan prinsip-prinsip ekonomi, namun koperasi harus tetap berpegangan pada prinsip koperasi yaitu demokratis sesama anggota. Agar dapat melakukan peran dan fungsinya dengan baik, maka KUD harus dikelolah secara produktif, efektif dan efisien untuk mewujudkan pelayanan usaha yang dapat meningkatkan nilai tambah dan manfaat yang sebesarbesarnya bagi anggota (Novianti, 2005 dalam Tumarjiyanto dan Salman, 2014).

Kabupaten Tanjung Jabung Barat merupakan salah satu kabupaten yang terletak di Provinsi Jambi. Koperasi-koperasi di Tanjung Jabung Barat telah tumbuh dan berkembang, seperti Koperasi Unit Desa (KUD), Koperasi KP RI, Koperasi Simpan Pinjam dan lain-lain. Jumlah Koperasi Unit Desa (KUD) di wilayah Tanjung Jabung Barat mengalami peningkatan pada tahun 2009-2013. Perkembangan KUD di Kabupaten Tanjung Jabung Barat mengalami perkembangan mencapai 8,8\%.

Kecamatan Tebing Tinggi merupakan Kecamatan yang terletak di Kabupaten Tanjung Jabung Barat. Sebagian besar penduduk di Kecamatan Tebing Tinggi bermata pencaharian sebagai petani kelapa sawit. Pada tahun 2014, Koperasi Unit Desa (KUD) di Kecamatan Tebing Tinggi berjumlah 7, maka dari itu Kecamatan ini memiliki jumlah Koperasi Unit Desa (KUD) terbanyak diantara kecamatan-kecamatan lain yang berada di Kabupaten Tanjung Jabung Barat. Dari ketujuh Koperasi Unit Desa (KUD) di Kecamatan Tebing Tinggi hanya terdapat 5 Koperasi Unit Desa (KUD) yang aktif, rutin dan tepat waktu menjalankan Rapat Anggaran Tahunan (RAT) yang didalamnya membahas tentang laporan keuangan, hal ini berarti jumlah Koperasi Unit Desa (KUD) yang aktif di Kecamatan Tebing Tinggi sebesar $71,4 \%$ dari jumlah Koperasi Unit Desa (KUD) keseluruhan. Kehadiran KUD di Kecamatan Tebing Tinggi diharapkan mampu memberikan kontribusi yang besar bagi perkembangan masyarakat sekitar dan anggota koperasi (Diskoperindag Kabupaten Tanjung Jabung Barat. 2014).

Koperasi Unit Desa di Kecamatan Tebing Tinggi merupakan koperasi serba usaha yang bergerak dalam kegiatan perekonomian perdesaan khususnya sektor komoditas kelapa sawit. Jenis usahanya adalah usaha pemasaran TBS, angkutan, pupuk dan saprotan, simpanan pinjam dan Mini Market. Usaha ini dari tahun ke tahun berfluktuasi dalam penanaman Sisa Hasil Usaha (SHU). Pada tahun 2013 KUD Suka Makmur mengalami penurunan sebesar 25,1 \% dari tahun sebelumnya, KUD Sawit Mandiri mengalami penurunan sebesar 1,75 \% dari tahun sebelumnya, KUD Karya Mandiri mengalami penurunan sebesar $26 \%$ dari tahun sebelumnya, KUD Karya Tani mengalami penurunan sebesar 24,36 \% dari tahun sebelumnya, dan KUD Harapan Makmur mengalami penurunan sebesar 97,3 \% dari tahun sebelumnya. Terjadi naik turunnya Sisa Hasil Usaha (SHU) disebabkan karena semakin banyak biaya-biaya yang di keluarkan pada Koperasi Unit Desa (KUD) yang tidak diimbangin dengan pendapatan yang cukup. Penurunan pendapatan dikarenakan tonase buah segar yang dipasarkan dan pasokan TBS dari Kelompok Tani Harapan (KTH) mengalami penurunan, yang menyebabkan unit usaha angkutan juga mengalami penuruna. Sehingga KUD di Kecamatan Tebing Tinggi harus lebih memperhatikan untuk meningkatkan unit usaha agar Sisa Hasil Usaha yang diperoleh mengalami peningkatan.

Perkembangan hasil usaha dari koperasi secara keseluruhan dapat diketahui dari laporan keuangan yang disajikan berupa laporan neraca, laporan laba rugi dan perubahan modal (Munawir, 2010), melalui manajemen keuangan yang tepat, maka diharapkan semakin efisiensi. Kinerja keuangan menjadi alat untuk merencanakan tujuan kedepannya. Data yang dihasilkan laporan keuangan dapat digunakan dengan menggunakan analisis rasio. Analisis rasio berguna untuk mengetahui kinerja keuangan secara keseluruh dari waktu ke waktu. Analisis rasio terdiri dari lima kategori yang cocok utuk badan usaha seperti koperasi yaitu: likuiditas, solvabilitas, rentabilitas, dan aktivitas (Rasmussen, 2005 dalam Tumarjiyonto dan Salman, 2014).

Penelitian ini dilakukan dengan tujuan untuk mengetahui kondisi keuangan Koperasi Unit Desa (KUD), untuk mengetahui kinerja keuangan Koperasi Unit Desa dan untuk mengetahui manfaat koperasi bagi anggota di Kecamatan Tebing Tinggi Kabupaten Tanjung Jabung Barat. 


\section{METODE PENELITIAN}

Penelitian ini dilaksanakan di Kecamatan Tebing Tinggi Kabupaten Tanjung Jabung Barat. KUD yang dijadikan sampel ditentukan secara sengaja dengan pertimbangan KUD yang aktif atau menjalankan kegiatan usaha. Hal ini dikarenakan KUD yang aktif memiliki laporan keuangan yang akan dianalisis guna memprediksi keadaan keuangan sebagai upaya mempertahankan dan mengembangkan usaha KUD. KUD yang berada di Kecamatan Tebing Tinggi, hanya terdapat 5 KUD yang aktif dan rutin menjalankan Rapat Anggota Tahunan (RAT) setiap tahunnya yang terdiri dari KUD Suka Makmur, KUD Sawit Mandiri, KUD Karya Mandiri, KUD Karya Tani dan KUD Harapan Makmur. Penelitian ini ditujukan dengan menganalisis laporan keuangan lima tahun terakhir (periode 2010-2014) dan mendeskripsikan manfaat yang dirasakan anggota KUD yang terdiri dari manfaat sosial dan ekonomi. Teknik pengambilan sampel untuk anggota KUD nya menggunakan rumus dari Tora Tamane atau Slovin (Riduwan, 2009) sebagai berikut:

$$
\mathrm{n}=\frac{\mathrm{N}}{\mathrm{Nd}^{2}+1}
$$

Dimana $: \mathrm{n} \quad=$ Jumlah sampel

$\mathrm{N} \quad=$ Jumlah populasi

$\mathrm{d}^{2} \quad=$ Presisi (ditetapkan 10\%)

Pengambilan sampel dengan rumus ini berguna untuk menambah tingkat ketelitian dalam penelitian ini. Untuk lebih jelasnya populasi dan jumlah anggota sampel di daerah penelitian dapat dilihat pada Tabel 1 :

Tabel 1. Populasi Anggota dan Jumlah Anggota Sampel di Daerah Penelitian Kecamatan Tebing Tinggi Kabupaten Tanjung Jabung Barat.

\begin{tabular}{lcc}
\hline \multicolumn{1}{c}{ Koperasi Unit Desa } & $\begin{array}{c}\text { Populasi } \\
\text { (Orang) }\end{array}$ & $\begin{array}{c}\text { Sampel } \\
\text { (Orang) }\end{array}$ \\
\hline KUD Suka Makmur & 1.258 & 34 \\
KUD Sawit Mandiri & 230 & 6 \\
KUD Karya Mandiri & 202 & 5 \\
KUD Karya Tani & 332 & 9 \\
KUD Harapan Makmur & 281 & 8 \\
\hline Total / Jumlah & $\mathbf{2 . 3 0 3}$ & $\mathbf{6 2}$ \\
\hline
\end{tabular}

Metode analisis data yang digunakan dalam penelitian ini adalah analisis kualitatif dan analisis kuantitatif. Analisis kualitatif digunakan untuk menjelaskan profil dan gambaran usaha KUD di Kecamatan Tebing Tinggi dan manfaat yang diperoleh anggota. Analisis kuantitatif yang digunakan untuk mengetahui keadaan keuangan dan kinerja keuangan KUD di Kecamatan Tebing Tinggi menggunakan analisis rasio keuangan dengan data keuangan yang diperoleh dari laporan keuangan (laporan neraca, rugi laba dan perubahan modal). Rasio keuangan tersebut terdiri dari:

1. Rasio Likuiditas
a. Rasio Lancar (Current Ratio) $=\frac{\text { Aktiva Lancar }}{\text { Hutang Lancar }} \times 100 \%$
b. Rasio Cepat (Quick Ratio) $=\frac{\text { Aktiva lancar }- \text { persediaan }}{\text { Hutang lancar }} \times 100 \%$
c. Rasio Kas (Cash Ratio) $=\frac{\text { Kas }+ \text { Bank }}{\text { Hutang Lancar }} \times 100 \%$
d. Inventory to Net Working Capital $=\frac{\text { Persediaan }}{\text { Aktiva Lancar }- \text { Hutang Lancar }} \times 100 \%$

2. Rasio Solvabilitas
a. Rasio Hutang atas Aktiva (Debt To Total Asset) $=\frac{\text { Total Hutang }}{\text { Total Aktiva }} \times 100 \%$
b. Rasio Hutang atas Modal Sendiri (Debt To Equity ratio) $=\frac{\text { Total Hutang }}{\text { Modal Sendiri }} \times 100 \%$ 
3. Rasio Profitabilitas
a. Net Profit Margin (NPM) $=\frac{\text { laba Besih }}{\text { Penjualan }} \times 100 \%$
b. Rentabilitas Ekonomi (Return On Investment) $=\frac{\text { laba Besih }}{\text { Total Aset }} \times 100 \%$
c. Rentabilitas Modal Sendiri (Return Of Equity) $=\frac{\text { laba Besih }}{\text { Modal Sendiri }} \times 100 \%$
d. Gross Profit Margin (GPM) $=\frac{\text { Penjualan Bersih }- \text { Harga Pokok Penjualan }}{\text { Penjualan }} \times 100 \%$

4. Rasio Aktivitas
a. Perputaran Persediaan (Inventory Trun Over) $=\frac{\text { Harga Pokok Penjualan }}{\text { Penjualan }} \times 100 \%$
b. Perputaran Harta Tetap (Fixed Assets Trun Over) $=\frac{\text { Penjualan }}{\text { Total Aktiva Tetap }} \times 100 \%$
c. Perputaran Harta (Total Assets Trun Over) $=\frac{\text { Penjualan }}{\text { Total Aktiva }} \times 100 \%$
d. Perputaran Piutang (Receivable Trun Over) $=\frac{\text { Penjualan }}{\text { Piutang Rata-rata }} \times 100 \%$

\section{HASIL DAN PEMBAHASAN}

\section{Kondisi Keuangan KUD di Kecamatan Tebing Tinggi}

Perbandingan kondisi keuangan digunakan untuk melihat keadaan keuangan masing-masing KUD yang dilihat dari perkembangan laporan neraca, laba rugi, dan perubahan modal. Untuk melihat perkembangan pertumbuhan komponen aktiva, hutang dan modal pada laporan neraca dapat dilihat pada Tabel 2.

Tabel 2. Perkembangan Nilai Komponen Aktiva, Hutang, dan Modal KUD di Kecamatan Tebing Tinggi Tahun 2010-2014.

\begin{tabular}{lccc}
\hline \multirow{2}{*}{ Nama KUD } & \multicolumn{3}{c}{ Rata-Rata Perkembangan (\%/thn) Laporan Neraca } \\
\cline { 2 - 4 } & Aktiva & Hutang & Modal \\
\hline Suka Makmur & 15,13 & $-0,12$ & 38,23 \\
Sawit Mandiri & 20,88 & 54,90 & 11,27 \\
Karya Mandiri & 5,57 & 32,86 & 20,70 \\
Karya Tani & 26,71 & 33,66 & 23,59 \\
Harapan Makmur & $-13,45$ & $-20,37$ & 21,56 \\
\hline Kecamatan & 10,97 & 20,18 & 23,07 \\
\hline
\end{tabular}

Menurut Harahap (2010), komponen laporan neraca terdiri dari aktiva (harta), hutang, dan modal. Tabel 2 dapat dilihat bahwa nilai rata-rata perkembangan aktiva KUD di Kecamatan Tebing Tinggi lebih tinggi sebesar 10,97 \% pertahun, walaupun perkembangan harta KUD di Kecamatan Tebing Tinggi tidak terlalu besar, namun KUD menunjukkan keadaan baik dalam meningkatkan kas, persediaan dan piutang yang dapat meningkatkan harta KUD. Perkembangan aktiva yang paling besar dimiliki KUD Karya Tani sebesar 26,71 \% pertahun, disusul oleh KUD Sawit Mandiri sebesar 15,13 \% pertahun, KUD Suka Makmur sebesar 15,13 \% pertahun dan KUD Karya Mandiri 5,57 \% pertahun. Hal ini menunjukkan KUD Karya Tani memiliki kondisi yang sangat baik dalam mengembangkan hartanya, karena mampu meningkatkan kas, persediaan, piutang, dan simpanan bank. KUD Harapan Makmur memiliki perkembangan aktiva yang sangat kecil yaitu sebesar $-13,45$ pertahun, hal ini dikarenakan kas, piutang, simpanan bank dan inventaris kantor yang dimiliki KUD mengalami penurunan.

Menurut harahap (2010) hutang adalah semua kewajiban keuangan koperasi kepada pihak lain yang belum terpenuhi. Perkembangan rata-rata hutang KUD di Kecamatan Tebing Tinggi sebesar 20,18\% pertahun, hal ini menunjukkan sebagian dana yang dimiliki koperasi untuk menjalankan usahanya berasal dari kreditor. Perkembangan rata-rata hutang KUD Sawit Mandiri menunjukkan perkembangan yang paling besar dibandingkan KUD yang berada di Kecamatan Tebing Tinggi, hal ini 
menunjukkan sebagian besar dananya berasal dari hutang dana SHU yang tidak dibagikan KUD kepada anggota, pengurus dan pembina yang telah disepakati bersama untuk ditanamkan sebagai modal KUD. Selanjutnya disusul oleh KUD Karya Tani sebesar 33,66 \% pertahun, KUD Karya Mandiri sebesar 32,86 \% pertahun dan KUD Harapan Makmur sebesar $-20,37 \%$ pertahun. KUD Suka Makmur memiliki perkembangan hutang yang paling kecil sebesar $-0,12 \%$ pertahun, hal ini menunjukkan bahwa KUD dalam keadaan baik, karena kegiatan usaha yang dilakukan KUD Suka Makmur sebagian besar diperoleh dari dana sendiri, dan KUD mampu mengecilkan hutang kepada pihak luar atau kreditor, sehingga KUD mampu melaksanakan kegiatan usahanya secara mandiri.

Modal merupakan unsur yang paling penting dalam melaksanakan kegiatan usaha. KUD di Kecamatan Tebing Tinggi menunjukkan perkembangan yang cukup besar yaitu 23,07 \% pertahun, hal ini menunjukan besarnya partisipasi anggota membayar simpanan pokok, wajib dan sukarela yang mampu meningkatkan modal KUD. Perkembangan modal yang paling besar yaitu KUD Suka Makmur sebesar 38,32 \% pertahun, hal ini karena banyaknya petani menjadi anggota di KUD Suka Makmur dan tingginya partisipasi anggota dalam membayar simpanan wajib dan simpanan pokok. Besarnya modal yang dimiliki koperasi menunjukkan KUD dalam keadaan sehat, karena semua usahanya sebagian besar dibiayai oleh modal yang dimiliki oleh KUD. Perkembangan modal terkecil yaitu KUD Sawit Mandiri sebesar 11,27 \% pertahun, hal ini karena kurangnya partisipasi anggota dan kecilnya iuran yang ditawarkan KUD untuk simpanan pokok dan simpanan wajib.

Perkembangan komponen laporan laba rugi antara masing-masing KUD tersebut dapat dilihat pada Tabel 3 yang berisi perkembangan Penjualan, SHU kotor dan SHU bersih sebagai berikut:

Tabel 3. Perkembangan Penjualan, SHU Kotor dan SHU Bersih KUD di Kecamatan Tebing Tinggi Tahun 2010-2014.

\begin{tabular}{lccc}
\hline \multirow{2}{*}{ Nama KUD } & \multicolumn{3}{c}{ Rata-Rata Perkembangan (\%/thn) Laporan Laba Rugi } \\
\cline { 2 - 4 } & Penjualan & SHU Kotor & SHU Bersih \\
\hline Suka Makmur & 15,20 & 6,35 & $-3,41$ \\
Sawit Mandiri & 3,31 & 3,82 & 15,88 \\
Karya Mandiri & 15,59 & 15,24 & 2,55 \\
Karya Tani & 13,72 & 18,44 & 33,54 \\
Harapan Makmur & $-3,39$ & $-18,73$ & $-132,46$ \\
\hline
\end{tabular}

Laporan laba rugi digunakan untuk menunjukkan kemampuan KUD dalam menghasilkan keuntungan dalam satu periode atau satu tahun (Rudianto, 2012). Dari Tabel 3 dapat dilihat bahwa KUD Karya Mandiri memiliki rata-rata perkembangan pendapatan dan penjualan paling tinggi sebesar 15,59 \% pertahun, disusul oleh KUD Suka Makmur sebesar 15,20 \% pertahun, KUD Karya Tani sebesar 13,72 \% pertahun, dan KUD Sawit Mandiri sebesar 3,31 \% pertahun. Tingginya perkembangan KUD Karya Mandiri karena dari tahun 2012-2014 penjualan dan pendapatannya mengalami peningkatan. Hal ini menunjukkan KUD Karya Mandiri dalam keadaan baik, karena mampu mengembangkan kegiatan usahanya dalam menyediakan kebutuhan anggota sehingga sebagian besar anggota sering melakukan pembelian saprotan dan pupuk, melakukan pinjaman, memasarkan TBS dan menggunakan jasa angkutan TBS. KUD Harapan Makmur memiliki rata-rata perkembangan yang paling kecil yaitu sebesar $-3,39 \%$ pertahun. Hal ini dikarenakan menurunnya unit usaha seperti pemasaran TBS, simpan pinjam, pupuk dan saprotan, angkutan TBS mengalami penurunan, sehinggan KUD Harapan Makmur dalam kodisi tidak baik, karena penjualan dan pendapatan KUD mengalami penurunan.

SHU kotor adalah selisih pendapatan, biaya operasi dan pajak yang harus dibayar oleh KUD. Rata-rata perkembangan SHU kotor paling tinggi yaitu KUD Karya Tani sebesar 18,44\% pertahun, hal ini karena penyediaan pupuk, saprodi dan obat-obatan sesuai dengan permintaan anggota, sehingga sedikitnya stock awal yang tersedia di KUD yang mengakibatkan kecilnya Harga Pokok Penjualan dan meningkatnya SHU kotor yang diperoleh KUD. Rata-rata perkembangan SHU Kotornya KUD Harapan Makmur menunjukkan perkembangan yang paling kecil dibandingkan KUD di Kecamatan Tebing Tinggi sebesar -18.73\% pertahun. Hal ini dikarenakan pada tahun 2012-2014, SHU kotor yang diperoleh KUD 
Harapan Makmur terus mengalami penurunan dan kurang sesuainya pembelian barang dengan permintaan petani yang menyebabkan banyaknya stock awal yang tersedia baik pupuk dan obatobatan, mengakibatkan nilai Harga Pokok Penjualan KUD tinggi dan SHU kotor yang diperoleh KUD kecil.

SHU bersih adalah pendapatan koperasi yang diperoleh dikurangi biaya, penyusutan dan kewajiban lainnya termasuk pajak dalam satu tahun. Rata-rata perkembangan SHU Bersih pertahun tertinggi yaitu KUD Karya Tani sebesar 33,54 \% pertahun, disusul oleh KUD Karya Mandiri dan KUD Sawit Mandiri. Besarnya perkembangan SHU KUD Karya Tani disebabkan meningkatnya pendapatan dan penjualan yang diimbangi dengan biaya yang dikeluarkan KUD untuk melaksanakan kegiatan usaha yang kecil, sehingga SHU yang diperoleh KUD cukup besar. Perkembangan SHU yang diperoleh KUD Suka Makmur sebesar -3,41 \% pertahun, yang menunjukkan perkembangan yang paling kecil dibandingkan KUD yang berada di Kecamatan Tebing Tinggi, hal ini karena pada tahun 2013 SHU KUD mengalami penurunan yang cukup besar yang disebabkan menurunnya pendapatan unit pemasaran TBS dan angkutan TBS yang tidak diimbangi dengan meningkatnya biaya operasional dan adm yang dikeluarkan untuk melaksanakan kegiatan usaha KUD yang menyebabkan SHU mengalami penurunan.

Untuk melihat perbandingan laporan perubahan modal antara masing-masing KUD tersebut yang terdiri dari rata-rata perkembangan modal tahun sebelumnya dan modal tahun berjalan maka dapat dilihat pada Tabel 5 sebagai berikut:

Tabel 4. Perbandingan Rata-Rata Perubahan Modal KUD di Kecamatan Tebing Tinggi Tahun 20102014.

\begin{tabular}{lcc}
\hline \multirow{2}{*}{ Nama KUD } & Rata-Rata Perkembangan (\%/thn) Laporan Perubahan Modal \\
\cline { 2 - 3 } & Tahun Sebelumnya & Tahun Berjalan \\
\hline Suka Makmur & 51,48 & 38,23 \\
Sawit Mandiri & 15,64 & 11,27 \\
Karya Mandiri & 21,94 & 20,70 \\
Karya Tani & 28,50 & 23,59 \\
Harapan Makmur & 7,40 & $-6,94$ \\
\hline Kecamatan & 24,9 & 17,37 \\
\hline
\end{tabular}

Suyanto (2013) menyebutkan bahwa laporan perubahan modal adalah laporan yang menggambarkan mengenai perubahan modal yang terjadi selama periode tertentu. Dari Tabel 4 dapat dilihat bahwa perkembangan modal yang dimiliki KUD di Kecamatan Tebing Tinggi sebesar $24,9 \%$ pertahun, hal ini menunjukkan tingginya partisipasi anggota dalam membayar simpanan wajib, simpanan pokok, simpanan sukarela dan partisipasi anggota dalam membeli kebutuhannya di koperasi. KUD Suka Makmur memiliki perkembangan modal tertinggi sebesar 51,48 \% pertahun, disusul oleh KUD Karya Tani, Karya Mandiri dan Sawit Mandiri. Sedangkan KUD Harapan Makmur memiliki rata-rata perkembangan modal terkecil yaitu sebesar $7,40 \%$ pertahun. Hal ini karena kurangnya partisipasi anggota dalam membayar simpanan wajib, simpanan pokok, dan kecilnya SHU yang diperoleh sehingga perkembangan dana cadangan kopersi keci.

Rata-rata perkembangan modal tahun berjalan KUD di Kecamatan Tebing Tinggi sebesar 17,37 \% pertahun, hal ini menunjukkan KUD dalam keadaan baik karena mampu meningkatkan modal yang cukup besar dari tahun sebelumnya. rata-rata perkembangan modal tahun berjalan yang paling tingg dimiliki oleh KUD Suka Makmur sebesar 38,23 \% pertahun, disusul KUD Karya Tani sebesar 23,59 \% pertahun, KUD Karya Mandiri sebesar 20,70 \% pertahun, dan KUD Sawit Mandiri sebesar 11,27 \% pertahun. Besarnya perkembangan modal tahun berjalan KUD Suka Makmur karena meningkatnya cadangan koperasi dan SHU yang mempengaruhi penambahan modal KUD Suka Makmur. Sedangkan KUD Harapan Makmur memiliki perkembangan modal tahun berjalan terkecil sebesar $-6,94 \%$ pertahun, hal ini disebabkanmenurunnya cadangan koperasi dan partisipasi anggota dan modal dari luar cenderung tidak mengalami penurunan, sehingga KUD menunjukkan kondisi kurang sehat dimana semua usahanya sebagian besar dibiayai oleh modal dari luar KUD.

Analisis Kinerja Keuangan Koperasi Unit Desa di Kecamatan Tebing Tinggi. 
Setelah mengetahui keadaan keuangan KUD, hal yang perly dilakukan adalah menganalisis kinerja keuangan KUD yang dilakukan melalui pendekatan rasio keuangan. Perhitungan rasio keuangan ini dijadikan tolak ukur kinerja keuangan KUD yang tidak cukup digambarkan dari laporan keuangan saja. Rasio keuangan yang digunakan adalah rasio likuiditas, rasio solvabilitas, rasio profitabilitas, dan rasio aktivitas.

Tabel 5. Perbandingan Rata-Rata Rasio Likuiditas KUD di Kecamatan Tebing Tinggi Tahun 20102014.

\begin{tabular}{lcccc}
\hline \multicolumn{1}{c}{ Nama KUD } & Rasio Lancar (\%) & Rasio Cepat (\%) & Rasio Kas (\%) & NWC (\%) \\
\hline Suka Makmur & 177,00 & 134,72 & 50,65 & 316,79 \\
Sawit Mandiri & 358,20 & 358,20 & 177,99 & - \\
Karya Mandiri & 235,38 & 223,36 & 57,02 & 16,10 \\
Karya Tani & 161,68 & 88,20 & 13,56 & 98,44 \\
Harapan Makmur & 225,22 & 223,30 & 51,80 & 2,00 \\
\hline Kecamatan & 231,50 & 205,56 & 70,60 & 86,67 \\
\hline
\end{tabular}

Dilihat dari rasio likuiditas pada Tabel 5, rata-rata rasio lancar KUD di Kecamatan Tebing Tinggi adalah sebesar $231,50 \%$, artinya koperasi memiliki aktiva lancar sebesar $231,50 \%$ dari hutang lancar, dengan kata lain bahwa setiap Rp 100 hutang lancar mampu dijamin oleh aktiva lancar sebesar Rp 231,50 aktiva lancar. Rasio lancar pada KUD di Kecamatan Tebing Tinggi dalam keadaan baik menjamin hutang dengan aktiva lancar, karena nilai yang didapat melebihi standar $200 \%$ yang merupakan standar Suwandi (1982) dalam Nadia (2014). Jika dibandingkan dengan hasil penelitian Khoirotunnisak (2008) yang memiliki nilai rata-rata rasio lancar sebesar 204,86 \%, maka KUD di Kecamatan Tebing Tinggi berada pada kondisi yang sangat baik dalam menjamin hutang lancar dengan menggunakan aktiva lancar. Dilihat masing-masing KUD, KUD Suka Makmur dan KUD Karya Tani berada dalam keadaan yang kurang lancar membayar hutang jangka pendeknya dengan aktiva lancar dikarekana berada dibawah standar acuan. Sedangkan KUD Sawit Mandiri, KUD Karya Mandiri dan KUD Harapan Makmur dalam keadaan baik menjamin hutang jangka pendeknya dengan aktiva lancar karena berada diatas standar acuan.

Rata-rata rasio cepat, KUD di Kecamatan Tebing Tinggi yaitu 205,56 \%. Artinya koperasi memiliki aktiva lancar tanpa menggunakan persediaan sebesar $205,56 \%$ dari total hutang lancar, atau dengan kata lain bahwa setiap Rp 100 hutang lancar dapat dijamin oleh aktiva lancar sebesar Rp 205,56 \% tanpa memperhatikan persediaan. KUD di Kecamatan Tebing Tinggi tergolong baik, karena berada diatas standar acuan yaitu $150 \%$. Persediaan tidak dimasukan dalam perhitungan rasio cepat karena memerlukan waktu yang cukup lama untuk dicairkan menjadi uang kas. Jika dibandingkan dengan hasil penelitian Teni Kartika (2011) yang memiliki nilai rata-rata rasio cepat tertinggi sebesar $140 \%$, maka KUD di Kecamatan Tebing Tinggi berada pada kondisi yang sangat baik dalam menjamin hutang lancar dengan menggunakan aktiva lancar tanpa memperhatikan persediaan. KUD Suka Makmur dan KUD Karya Tani berada dalam keadaan yang kurang baik melunasi hutang lancarnya dengan aktiva lancar tanpa memperhatikan persediaan karena berada dibawah standar acuan. Sedangkan KUD Sawit Mandiri, KUD Karya Mandiri dan KUD Harapan Makmur dalam keadaan baik menjami hutang lancar dengan aktiva lancar tanpa menggunakan persediaan.

Rata-rata rasio kas, nilai rata-rata rasio kas KUD di Kecamatan Tebing Tinggi yaitu 70,60 \%. Artinya koperasi memiliki kas sebesar $70,60 \%$ dari total hutang lancar, atau dengan kata lain bahwa setiap Rp 100 hutang lancar mampu dijamin oleh kas dan bank sebesar 70,60. KUD di Kecamatan Tebing Tinggi berada dalam keadaan yang kurang baik dalam menjamin hutang lancarnya dengan kas dan bank, karena berada dibawah standar acuan yaitu $100 \%$, Menurut Suharto (2005) dalam Khoirotunnisak (2008). Jika dibandingkan penelitian Nadia (2014) yang memiliki nilai rata-rata rasio kas tertinggi sebesar 315,11 \%, maka KUD di Kecamatan Tebing Tinggi berada kondisi tidak baik karena memiliki kas dan simpanan bank yang sangat kecil sehingga belum mampu menjamin hutang 
lancar yang dimiliki. Kas yang terlalu sedikit dapat memperlambat kegiatan koperasi dan menghambat dalam memenuhi kewajibannya.

Inventory to net working capital, nilai rata-rata rasio NWC pada KUD di Kecamatan Tebing Tinggi yaitu 86,67 \%, yang artinya kemampuan KUD dalam perputaran modal kerja dengan menunjukkan jumlah yang diperoleh penjualan dari setiap modal kerja sebesar $86,67 \%$, dengan kata lain setiap Rp 100 modal kerja akan dijamin oleh persediaan sebesar Rp 86,67. Maka KUD di Kecamatan Tebing Tinggi berada dalam keadaan tidak baik dalam perputaran kerjanya karena berada dibawah standar acuan yaitu 100 \%. Rata-rata nilai rasio NWC KUD Karya Mandiri, KUD Karya Tani dan KUD Harapan Makmur masih berada dibawah standar acuan yang digunakan. Keadaan ketiga KUD tersebut kurang baik, ini berpengaruh pada modal kerja koperasi yang lambat pada perputaran kerjanya. KUD Sawit Mandiri tidak ada persediaan, oleh karena itu nilai NWC dari KUD Sawit Mandiri bernilai nol (0) karena persediaan KUD Sawit Mandiri habis terjual.

Untuk menjalankan usahanya, KUD tidak terlepas dari hutang pada pihak lain. Untuk mengukur kemampuan KUD dalam melunasi semua kewajibanya maka digunakan perhitungan solvabilitas yang disajikan pada Tabel 6.

Tabel 6. Perbandingan Rata-Rata Rasio Solvabilitas KUD di Kecamatan Tebing Tinggi Tahun 20102014.

\begin{tabular}{lcc}
\hline \multicolumn{1}{c}{ Nama KUD } & Debt to Asset Ratio (\%) & Debt ofEquity Ratio (\%) \\
\hline Suka Makmur & 41,91 & 87,90 \\
Sawit Mandiri & 34,64 & 51,66 \\
Karya Mandiri & 33,30 & 51,33 \\
Karya Tani & 60,39 & 157,48 \\
Harapan Makmur & 45,51 & 87,91 \\
\hline Kecamatan & 43,15 & 87,26 \\
\hline
\end{tabular}

Dilihat dari rasio solvabilitas pada Tabel 6, rata-rata debt to asset ratio (DtAR)KUD di Kecamatan Tebing Tinggi adalah sebesar 43,15 \%. Artinya kemampuan KUD dalam memenuhi kewajiban sebesar Rp 43,15 dari 1 rupiah aktiva dijadikan jaminan hutang, dengan kata lain setiap Rp 100 jumlah aktiva digunakan untuk menjamin total hutang sebesar Rp 43,15. Hal ini menunjukkan bahwa kemampuan dalam memenuhi kewajiban cukup baik, karena tidak lebih dari separo jumlah aktiva dijadikan jaminan hutang. Rasio DtAR pada KUD di Kecamatan Tebing Tinggi tergolong baik karena sesuai dengan standar yang digunakan yaitu kecil dari $50 \%$. Rata-rata rasio DtAR KUD Suka Makmur, Sawit Mandiri, Karya Mandiri dan Harapan Makmur tergolong baik dalam memenuhi kewajibannya. Sedangkan KUD Karya Tani tergolong tidak baik dalam memenuhi kewajibannya karena berada diatas standar acuan, hal ini karena lebih separo jumlah aktiva dijadikan jaminan hutang.

Rata-rata debt of equity ratio (DtER) pada KUD di Kecamatan Tebing Tinggi yaitu 87,26\%. Artinya kemampuan KUD dalam memenuhi seluruh hutangnya yang dijamin sepenuhnya oleh modal sendiri sebesar $87,26 \%$, dengan kata lain setiap Rp 100 modal akan digunakan untuk menjamin total hutang sebesar Rp 87,26.Nilai DtER pada KUD di Kecamatan Tebing Tinggi sudah tergolong baik karena telah memenuhi standar yaitu lebih dari $50 \%$. KUD di Kecamatan Tebing Tinggi sudah mampu menjamin seluruh utang dengan modal sendiri yang dimilikinya. Hal ini disebabkan oleh modal sendiri mengalami peningkatan yang lebih besar dibandingkan peningkatan hutang. Nilai ratarata rasio DtER KUD Karya Tani sebesar 157,48 \%, hal ini menunjukkan bahwa kemampuan KUD Karya Tani dalam memenuhi kewajibannya rendah dibandingkan dengan KUD yang lain. Nilai ratarata DtER terendah dimiliki oleh KUD Karya Mandiri sebesar 51,33 \%. Hal ini KUD Karya Mandiri berada dalam keadaan yang baik, karena total modal yang digunakan untuk menjamin total hutang hanya sedikit.

Rasio profitabilitas digunakan untuk mengetahui kemampuan KUD memperoleh laba dalam bentuk Sisa Hasil Usaha (SHU). Untuk melihat perbandingan rata-rata rasio profitabilitas KUD di KecamataN Tebing Tinggi dapat dilihat pada Tabel 7. 
Tabel 7. Perbandingan Rata-Rata Rasio Profitabilitas KUD di Kecamatan Tebing Tinggi Tahun 20102014.

\begin{tabular}{lcccc}
\hline \multicolumn{1}{c}{ Nama KUD } & $\begin{array}{c}\text { Net Profit } \\
\text { Margin } \\
(\%)\end{array}$ & $\begin{array}{c}\text { Rentabilitas } \\
\text { Ekomi (ROI) (\%) }\end{array}$ & $\begin{array}{c}\text { Rentabilitas } \\
\text { Modal Sendiri } \\
\text { (ROE) (\%) }\end{array}$ & $\begin{array}{c}\text { Gross Profit } \\
\text { Margin (\%) }\end{array}$ \\
\hline Suka Makmur & 0,66 & 12,87 & 26,03 & 1,64 \\
Sawit Mandiri & 59,61 & 17,74 & 23,72 & 64,74 \\
Karya Mandiri & 43,73 & 24,99 & 37,37 & 56,36 \\
Karya Tani & 34,25 & 3,29 & 57,94 & 4,78 \\
Harapan Makmur & 13,90 & 8,76 & 18,84 & 11,62 \\
\hline Kecamatan & 30,43 & 17,53 & 32,78 & 34,12 \\
\hline
\end{tabular}

Dilihat dari rasio profitabilitas pada Tabel 7, Rasio net profit margin (NPM), KUD di Kecamatan Tebing Tinggi sebesar 30,43\%. Artinya kemampuan KUD dalam memperoleh keuntungan bersih dari setiap penjualan sebesar 30,43 \%, dengan kata lain bahwa setiap Rp 100 penjualan turut berkontribusi menciptakan Rp 30,43 laba bersih. Berdasarkan dari standar acuan sebesar $4 \%$, maka nilai rata-rata NPM KUD di Kecamatan Tebing Tinggi berada di atas standar yang menandakan bahwa kemampuan KUD tersebut dalam menghasilkan laba bersih dan penjualan tergolong baik. Penjualan barang dan pendapatan jasa yang lebih tinggi dibandingkan harga pokok penjualan serta biaya operasional atau biaya yang harus dikeluarkan KUD yang rendah. Sehingga NPM yang dihasilkan KUD sangat Tinggi dimana kegiatan usaha yang dilakukan KUD banyak memiliki keuntungan. Nilai ratarata NPM KUD Suka Makmur adalah yang terkecil 0,66 \%, hal ini KUD Suka Makmur tergolong buruk dibandingkan KUD lainnya dalam menghasilkan laba bersih dan penjualan, karena nilai NPM nya berda dibawah standar acuan yang digunakan.

Rata-rata rasio rentabilitas ekonomi (ROI), KUD di Kecamatan Tebing Tinggi adalah sebesar 17,53 \%, kemampuan KUD menghasilkan laba dari dana yang ditanamkan dalam total aktivasebesar 17,533\%, dengan kata lain bahwa setiap Rp 100 dana yang ditanamkan dalam total aktivaakan menghasilkan laba bersih sebesar Rp 17,53.KUD diKecamatan Tebing Tinggi sudah dapat memenuhi standar yang digunakan dalam penelitian ini yaitu sebesar $5 \%$. Hal ini menunjukkan kemampuan koperasi dalam menghasilkan SHU dari total aktivanya sudah cukup baik. SHU yang digunakan untuk anggota dan dana-dana SHU yang lain sebesar $60 \%$ dari total SHU, sedangkan $40 \%$ digunakan untuk cadangan KUD yang kemudian akan ditanamkan dalam modal sendiri. Jika dibandingkan dengan hasil penelitian Nadia (2014) yang memiliki nilai rata-rata rasio TOI tertinggi sebesar 11,20\%, maka KUD di Kecamatan Tebing Tinggi memiliki kemampuan lebih tinggi menghasilkan laba dari dana yang ditanamkan dalam total aktiva. Kelima KUD di Kecamatan Tebing Tinggi tergolong baik dalam menghasilkan laba bersih, karena nilai rata-rata ROI berada diatas standar acuan.

Rata-rata rasio rentabilitas modal sendiri (ROE), KUD di Kecamatan Tebing Tinggi sebesar 32,78 \%. Artinya setiap Rp 100 dana yang ditanamkan dalam modal akan menghasilkan laba bersih sebesar Rp 32,78. KUD di Kecamatan Tebing Tinggi tergolong baik dalam menghasilkan laba bersih setelah pendapatan dan beban-beban lain atau SHU, karena lebih dari standar yaitu $15 \%$. Semakin besar SHU maka akan semakin besar modal KUD karena $40 \%$ dari SHU akan digunakan sebagai modal. Namun usaha yang dilakukan KUD dapat berkembang dengan cukup baik sehingga hasil usaha yang diperoleh lebih besar dibandingkan dengan modal yang digunakan. Jika dilihat nilai ratarata ROE kelima KUD berada diatas standar acuan dan termasuk dalam kriteria baik, karena koperasi tersebut mampu menghasilkan laba bersih. Jika dibandingkan dengan hasil penelitian Yeni Kartika (2011) yang memiliki nilai rata-rata rasio ROE tertinggi $9 \%$, maka KUD di Kecamatan Tebing Tinggi berada jauh lebih tinggi menghasilkan laba bersih setelah pendapatan dan beban lain-lain.

Rata-rata gross profit margin (GPM), KUD di Kecamatan Tebing Tinggi sebesar 34,12 \%. Artinya setiap Rp 100 penjualan akan menghasilkan laba (SHU) kotor sebesar 34,12.KUD di Kecamatan Tebing Tinggi tergolong baik karena lebih dari standar yang ditentukan yaitu $4 \%$. Hal ini membuktikan bahwa usaha yang dijalankan KUD di Kecamatan Tebing Tingi sudah efisien dari sisi 
laba bersih yang dihasilkan karena kecilnya Harga Pokok Penjualan dan stok akhir yang tidak terlalu banyak, selain itu beban biaya operasi yang dikeluarkan KUD rendah, tingkat penjualan terhadap barang-barang dan pendapatan jasa cukup besar dihasilkan oleh KUD. Dilihat masing-masing KUD, KUD Suka Makmur memiliki nilai GPM dibawah standar. Hal ini KUD Suka Makmur masih belum efisien dari sisi laba yang dihasilkan karena besarnya HPP dan biaya operasional yang harus dikeluarkan KUD.

Kegiatan usaha yang disajikan oleh KUD tidak terlepas dari perputaran nilai aktiva dan aset yang dapat diukur keefektivitasnya dengan menggunakan rasio aktivitas yang disajikan pada Tabel 8 .

Tabel 8. Perbandingan Rata-Rata Rasio Aktivitas KUD di Kecamatan Tebing Tinggi Tahun 20102014.

\begin{tabular}{lcccc}
\hline Nama KUD & $\begin{array}{c}\text { Perputaran } \\
\text { Persediaan } \\
\text { (ITO) }\end{array}$ & $\begin{array}{c}\text { Perputaran } \\
\text { Aktiva Tetap } \\
\text { (FATO) }\end{array}$ & $\begin{array}{c}\text { Perputaran Total } \\
\text { Aktiva (TATP) }\end{array}$ & $\begin{array}{c}\text { Perputaran } \\
\text { Piutang (RTO) }\end{array}$ \\
\hline Suka Makmur & 199,63 & 76,04 & 19,22 & 65,18 \\
Sawit Mandiri & - & 1,23 & 0,30 & 4,03 \\
Karya Mandiri & 16,16 & 21,48 & 0,56 & 1,42 \\
Karya Tani & 1,54 & 24,82 & 0,69 & 1,83 \\
Harapan Makmur & 161,56 & 26,59 & 0,59 & 3,88 \\
\hline Kecamatan & 30,43 & 30,03 & 4,27 & 15,26 \\
\hline
\end{tabular}

Dilihat dari rasio aktivitas pada Tabel 9, rata-rata rasio perputaran persediaan, KUD di Kecamatan Tebing Tinggi memiliki nilai ITO sebesar 59,78 kali. Artinya dana yang ditanamkan dalam persediaan hanya mampu berputar sebanyak 59,78 kali dalam 1 tahun.Secara kerseluruhan KUD di Kecamatan berada dalam keadaan baik, karena lebih dari standar acuan yang digunakan yaitu 10 kali. Hal inimenunjukkan kemampuan KUD termasuk kriteria baik dalam memutarkan barang dagangnya yang menunjukkan penggunaan persedian sudah efektif. Hal ini dikarenakan persediaan pupuk dan obat-obatan dilakukan sesuai pemesanan dari anggota. Makin tinggi perputaran persediaan berarti makin pendek terikatnya modal dalam persediaan, sehingga kelebihan modal yang digunakan untuk persediaan dapat diinvestasikan pada aktiva lain. Nilai rata-rata ITO terendah yaitu KUD Karya Tani sebesar 1,54 kali, maka KUD tersebut berada dalam keadaan yang tidak baik karena berada dibawah acuan.

Rata-rata rasio perputaran aktiva tetap (FATO), KUD di Kecamatan Tebing Tinggi sebesar 30,03 kali. Artinya dana yang ditanamkan dalam aktiva tetap hanya berputar sebanyak 20,03 kali dalam 1 tahun. KUD di Kecamatan Tebing Tinggi memiliki kondisi yang paling baik, karena nilai ini berada diatas standar Suwandi yaitu 10 kali. Ini menunjukkan adanya efektivitas dalam penggunaan aktiva tetap dalam menghasilkan penjualan. KUD yang memiliki nilai FATO tertinggi adalah KUD Suka Makmur sebesar 76,04, maka nilai ini menunjukkan efektivitas dalam penggunaan aktiva tetap yang baik. KUD Sawit Mandiri memiliki FATO terndah sebesar 1,23 kali. Hal ini menggambarkan bahwa KUD Sawit Mandiri berada pada kondisi yang paling buruk diantara semua KUD yang berada di Kecamatan Tebing Tinggi.

Rata-rata rasio perputaran total aktiva (TATO),KUD di Kecamatan Tebing sebesar 4,27 kali. Artinya dana yang ditanamkan dalam total assets akan berputar sebanyak 4,27 kali dalam 1 tahun. Secara kerseluruhan KUD di Kecamatan berada dalam keadaan tidak baik, karena berada dibawah standar acuan yang digunakan yaitu 5 kali. Hal ini menunjukkan rendahnya kemampuan KUD di Kecamatan Tebing Tinggi dalam penggunaan asset dalam menghasilkan penjualan dan tingkat efisiensi penggunaan harta sangat kecil. KUD Sawit Mandiri, KUD Karya Mandiri, KUD Karya Tani dan KUD Harapan Makmur, menunjukkan kondisi yang tidak sehat dalam perputaran total aktiva, karena berada dibawah standar acuan. Sedangkan KUD Suka Makmur menunjukkan kondisi yang baik dalam perputaran total aktiva, karena berada diatas standar acuan.

Rata-rata rasio perputaran piutang, KUD di Kecamatan Tebing Tinggi sebesar 15,26 kali. Artinya setiap penjualan dengan piutang berputar sebanyak 15,26 kali dalam satu tahun. KUD di 
Kecamatan Tebing Tinggi berada pada kriteria baik, yang menunjukkan efektivitasnya penggunaan piutang dalam kegiatan operasional yang dilakukan KUD, karena berada diatas standar yang ditetapkan Suwandi yaitu sebesar 10 kali. Hal ini menunjukkan piutang anggota lebih kecil dibandingkan perputaran modal. Jika dilihat dari nilai rata-rata perputaran piutang masing-masing KUD, maka nilai tertinggi dimiliki oleh KUD Suka Makmur sebesar 65,18 kali, yang berarti bahwa KUD Suka Makmur berada dalam kondisi yang baik dibandingkan dengan KUD lainnya, karena berada diatas standar acuan. Nilai rata-rata perputaran piutang terkecil dimiliki oleh KUD Karya Mandiri sebesar 1,42 kali, yang berarti bahwa KUD Karya Mandiri berada pada kondisi yang tidak sehat dibandingkan dengan KUD Lain.

\section{Manfaat yang Dirasakan Anggota Pada Koperasi Unit Desa di Kecamatan Tebing Tinggi.}

Koperasi dikatakan berhasil atau sukses jika mampu meningkatkan kesejahteraan anggotanya dengan memberikan manfaat sosial dan ekonomi yang dirasakan oleh anggota. Manfaat sosial misalnya hubungan kekerabatan sesama anggota, maupun penguru, pelayanan dan fasilitas yang tersedia dan pembinaan serta pelatihan. Manfaat ekonomi terdiri dari pendapatan yang diterima anggota, sisa hasil usaha (SHU), kepuasan terhadap harga pupuk dan saprodi yang ditawarkan KUD, kemudahan memperoleh pupuk dan saprodi, kemudahan melakukan pinjaman dan pengembaliannya, serta jasa yang ditawarkan KUD.

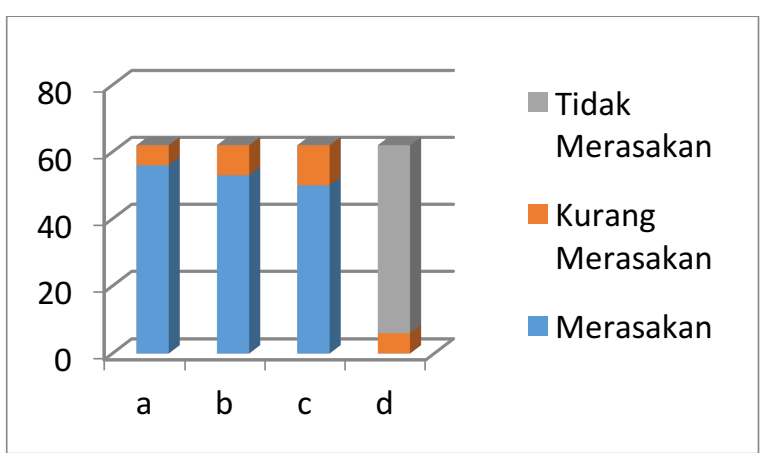

\section{Gambar 1. Manfaat Sosial yang dirasakan anggota KUD}

Keterangan:

a. Hubungan anda sebagai anggota dengan anggota koperasi yang lainnya dinilai sudah baik

b. Hubungan anda sebagai anggota dengan pengurus koperasi sudah baik

c. Pelayanan dan fasilitas yang disediakan koperasi sudah baik

d. Pembinaan dan pelatihan yang diberikan oleh koperasi sudah sesuai kebutuhan anggota.

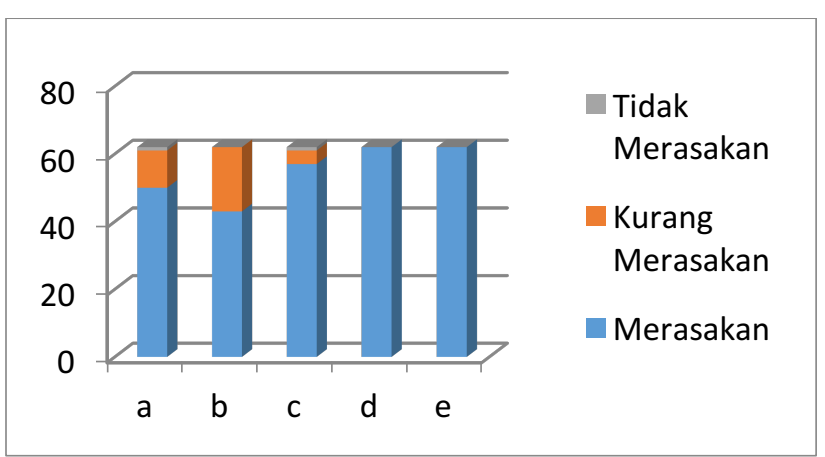

\section{Gambar 2. Manfaat ekonomi yang dirasakan anggota KUD}

Keterangan:

a.Merasakan adanya penambahan pendapatan setelah menjadi anggota KUD

b.Merasakan adanya penambahan pendapatan setelah menjadi anggota KUD

c.Merasakan kemudahan memperoleh pupuk, saprodi, dan obat-obatan yang disediakan KUD

d.Merasakan kemudahan memperoleh pinjaman

e.Merasakan keringan bunga bila meminjam di KUD

Hubungan anggota dengan pengurus atau karyawan Koperasi Unit Desa di Kecamatan Tebing Tinggi merasa puas sebesar $85,5 \%$. Hubungan kerjasama sebesar $90 \%$, dimana adanya kerjasama yang baik dengan sesama anggota atau sesama anggota kelompok taninya. Namun anggota KUD Harapan Makmur kurang merasakan adanya kerjasama dengan sesama anggota, hal ini dikarekan pertemuan hanya terbatas pada saat RAT jika mendapatkan undangan dan hubungan tersebut kurang adanya interaksi antar sesama anggota yang mengakibatkan anggota merasa kurang merasakan hubungan kerjasama antar anggota. Anggota KUD tidak ada yang merasakan kepuasan terhadap pembinaan dan pelatihan sebesar $89 \%$, hal ini dikarenakan pembinaan dan pelatihan hanya diberikan ketika awal-awal pembukaan KUD, dan materi pelatihan yang diterima anggota hanya mengenai pelaksanaan simpan pinjam, sedangkan masih banyak materi yang dibutuhkan oleh 
petani yaitu tentang usahatani dalam pasca panen, dan informasi penjualan, pendidikan dasar tentang koperasi dan informasi penjualan.Anggota merasa cukup puas sebesar $76 \%$ dalam pelayanan yang diberikan KUD, hal ini dikarenakan pengurus atau karyawan KUD tanggap terhadap anggotanya dan terjalin interaksi yang harmonis antara anggota dan pengurus. Namun anggota di KUD Harapan Makmur masih kurang merasakan kepuasan pelayanan yang diberikan KUD tersebut. Hal ini karenakan pelayanan karyawan KUD terhadap anggota kurang tanggap dan kurang terjalin interaksi hanya sebatas anggota sebagai pelanggan.

Manfaat ekonomi memberi gambaran terhadap reaksi anggota terhadap aktivitas penjualan yang dilakukan oleh KUD di Kecamatan Tebing Tinggi.Pendapatan SHU yang diterima setiap anggota dalam penelitian ini cukup puas sebesar $81 \%$. Hal ini dikarenakan SHU yang dibagikan sama rata kepada setiap anggota dan SHU yang dibagikan kepada anggota sudah dapat meringankan beban kebutuhan anggota. Namun 17,74 \% anggota kurang memuaskan dalam pendapatan SHU yang diterima, karena SHU yang dibagikan kepada anggota di KUD Harapan Makmur belum dapat meringankan beban kebutuhan anggota. Kepuasan untuk harga pupuk anggota sudah merasa puas sebesar $92 \%$, karena harganya lebih murah dan dapat melakukan kredit dalam pembelian pupuk. Kepuasan dalam kemudahan memperoleh pupuk dikatakan memuaskan sebesar 68,35 \%, karena letaknya dekat. Namun $30,65 \%$ anggotanya masih kurang puas dikarenakan terbatasnya stok pupuk dan saprotan yang di jual KUD sehingga anggota harus membeli pupuk dan saprotan keluar yang memerlukan waktu dan letak yang jauh dari tempat anggota. Anggota merasa puas dalam memperoleh pinjaman juga sangat mudah tanpa banyak persyaratan, hanya menyerahkan fotokopi KTP, atau fotokopi Kartu Keluarga (KK) serta fotokopi kartu anggota. Dalam bunga pinjaman anggota merasa puas, karena masih rendah dari bunga bank dan rentenir. Pengembalian pinjaman KUD Sawit Mandiri, Karya Mandiri, dan Karya Tani diberikan jangka waktu 1 bulan, KUD Suka Makmur jangka waktu pengembalian pinjaman yaitu 1 tahun, sedangkan KUD Harapan Makmur walaupun dalam pengembalian pinjaman jangka pembayaran ditentukan oleh anggota sendiri. Walaupun ada anggota yang tidak tepat waktu dalam pengembalian, bunga yang dikenakan tetap tidak berubah.

\section{KESIMPULAN}

Koperasi unit Desa di Kecamatan Tebing Tinggi jika dilihat dari nilai rasio likuiditas cukup baik, namun rasio kas dan inventory to net working capital KUD memiliki nilai yang kecil, yang menyebabkan KUD kurang lancar dalam menjamin hutang jangka pendeknya menggunakan kas. Rasio solvabilitas dan rasio profitabilitas tergolong baik karena memiliki skor rata-rata yang telah memenuhi standar. Perputaran dana yang tertanam pada persediaan, aktiva tetap dan piutang cukup besar, namun dana yang tertanam dalam total aset tidak terlalu besar. Oleh karena itu KUD harus meningkatkan volume usaha dan penurunan biaya untuk meningkatkan kinerja keuangan KUD.

Peran KUD dapat memberikan manfaat sosial dan ekonomi, yang dirasakan oleh anggota dengan baik. Hal ini dikarenakan terjalinnya komunikasi yang baik pengurus dengan anggotanya, adanya kerjasama antar anggota, pelayanan yang baik, adanya sarana produksi, pupuk dan obatobatan yang dibutuhkan anggota dengan harga yang ditawarkan tidak memberatkan anggota. Pembagian SHU yang dibagikan secara adil, mudah memperoleh pinjaman dengan bunga yang kecil, namun manfaat yang diberikan KUD Harapan Makmur masih kurang dirasakan oleh anggota. Hal ini dikarenakan kurang terjalinnya komunikasi dengan anggota, kurang adanya pelatihan, kurangnya pelayanan, sarana produksi, pupuk dan obat-obatan yang dijual di KUD masih terbatas, dan pembagian SHU yang dibagikan belum dapat meringankan beban kebutuhan anggota.

\section{UCAPAN TERIMA KASIH}

Pada kesempatan kali ini penulis menyampaikan ucapan terima kasih kepada Dekan Fakultas Pertanian Universitas Jambi dan Ketua Jurusan Agribisnis Fakultas Pertanian Universitas Jambi yang 
telah memfasilitasi pelaksanaan penelitian ini. Selain itu ucapan terimakasih juga penulis sampaikan kepada Camat Tebing Tinggi serta pengurus Koperasi Unit Desa yang telah memfasilitasi penelitan di lapangan

\section{DAFTAR PUSTAKA}

Dinas Koperasi, Perindustrian dan Perdaganga. 2014. Daftar Koperasi di Kecamatan Tebing Tinggi. Diskoperindag. Tanjung Jabung Barat. Jambi

Harahap, Sofyan Syafri (2010). Analisis Kritis atas Laporan Keuangan. Edisi pertama. PT Rajagrafindo Persada. Jakarta.

Khoirotunnisak. 2008. Analisis Kinerja Keuangan Bayuwanik Di Kota Semarang. Skripsi Fakultas Pertanian Universitas Sebelas Maret Surakarta. Surakarta. http://eprints.uns.ac.id/10233/1/7679157200904231.pdf diundah tanggal 16 Febuari 2015.

Munawir. 2010. Analisis Laporan Keuangan. Edisi keempat. Liberty. Yogyakarta.

Nadia Yulia. 2014. Evaluasi Kinerja Keuangan Koperasi Unit Desa Di Kecamatan Sungai Bahar Kabupaten Muara Jambi. Skripsi Tidak Diterbitkan, Fakultas Universitas Jambi. Jambi.

Riduwan. 2009. Rumus dan Data Dalam Analisis Statistika. Alfabeta, Bandung.

Rudianto.2009. Pengantar Akuntansi. Erlangga. Jakarta.

Sunyoto, Danang. 2013. Analisis Laporan Keuangan Untuk Bisnis Teori dan Kasus. Center of Academic Publishing Service. Yogyakarta.

Tumarjiyanto dan Salman. 2014. Analisis Kinerja Keuangan Koperasi:Studi Kasus Pada KUD Manunggalabadi Di Desa Tapung Lestari Kecamatan Tapung Hilir Kabupaten Kampar. Jurnal Dinamika Pertanian Volume XXIX Nomor 1 April 2014. 